\title{
Strategy Analysis of Storytelling in Communicating Marriage Age Maturity Program in The Society
}

\section{Analisis Strategi Storytelling Dalam Mengomunikasikan Program Pendewasaan Usia Perkawinan Pada Masyarakat}

\author{
Nilam Wardasari1, Yun Fitrahyati Laturrakhmi², Azizun Kurnia Illahi ${ }^{3}$ \\ ${ }^{1}$ Program Studi Ilmu Komunikasi, Jurusan Ilmu Komunikasi, Fakultas Ilmu Sosial dan Ilmu \\ Politik, Universitas Brawijaya. Ketawanggede, Kec. Lowokwaru, Kota Malang, Jawa Timur \\ 65145 \\ Email: nilamwardasari@ub.ac.id \\ ${ }^{2}$ Program Studi Ilmu Komunikasi, Jurusan Ilmu Komunikasi, Fakultas Ilmu Sosial dan Ilmu \\ Politik, Universitas Brawijaya. Ketawanggede, Kec. Lowokwaru, Kota Malang, Jawa Timur \\ 65145 \\ Email: yun.fitrahyati@ub.ac.id \\ ${ }^{3}$ Program Studi Ilmu Komunikasi, Jurusan Ilmu Komunikasi, Fakultas Ilmu Sosial dan Ilmu \\ Politik, Universitas Brawijaya. Ketawanggede, Kec. Lowokwaru, Kota Malang, Jawa Timur \\ 65145* \\ Email: azizun.nia@ub.ac.id
}

Masuk tanggal : 22-02-2021, revisi tanggal : 01-08-2021, diterima untuk diterbitkan tanggal : 02-09-2021

\begin{abstract}
Even though some measures to reduce the incidence rate of child marriage have being undertaken for years, the implementation of the marriage act, Undang-undang No.16/2019, has been strengthening the implementation of Program Pendewasaan Usia Perkawinan (PUP), a national program to reduce the incidence rate of child marriage in Indonesia. Under these circumstances, communication holds an essential role in that program, mainly to reach behavioral and social changes among community as the main target of the program. A number of previous research still focused on the role of communicators and the communication effectiveness of the program. Through narrative paradigm framework, the present study is conducted to explore story-telling strategies performed by extension agents in Kabupaten Pasuruan, a distric where the incidence rate of child marriage is relatively high. Data gathered through FGDs and indepth interviews which involved extension agents of Program PUP in Kabupaten Pasuruan, local authority that concerns in family welfare and women empowerment, and Muslimat NU - those directly involved in the communication and education process towards PUP Program. Through interactive analysis presented by Miles, Huberman \& Saldana (2014), this study revealed that within their strory-telling strategies, the extension agents as a story-teller tends to performed themselves in a more symmetrical relationship with their audiences. In order to involve their audiences to their stories, the extension agents employed Islamic based stories. From the structural narration, it is clear that they use humor and mitos to convince their audiences to avoid child marriage. The stories used also performed both structural and characterological coherence. However, in some stories, there are still lack of material coherence.
\end{abstract}

Keywords: early marriage, narrative paradigm, strategies of communication, storytelling 


\begin{abstract}
Abstrak
Meskipun penanganan masalah pernikahan usia anak telah sejak lama dilakukan, berlakunya Undang-Undang Nomor 16 Tahun 2019 tentang perkawinan semakin memperkuat pelaksanaan Program Pendewasaan Usia Perkawinan (PUP) sebagai langkah konkret penanganan tingginya pernikahan usia anak di Indonesia. Komunikasi pada akhirnya turut memegang peranan kunci dalam proses pelaksanaan program khususnya untuk mencapai perubahan dalam level masyarakat sasaran. Berkaitan dengan PUP, berbagai riset terdahulu masih banyak berfokus pada peran komunikator serta efektivitas proses pengomunikasian program. Melalui kerangka narrative paradigm, penelitian ini hadir dengan tujuan mengeksplorasi strategi komunikasi berbasis storry-telling yang telah dilakukan oleh para penyuluh lapangan di wilayah Kabupaten Pasuruan, wilayah dengan jumlah pernikahan usia anak yang cukup tinggi. Teknik pengumpulan data dilakukan melalui FGD dan wawancara dengan melibatkan para penyuluh lapangan Program PUP di Kabupaten Pasuruan, dinas terkait, serta Muslimat NU yang terlibat langsung dalam proses edukasi terkait PUP. Melalui analisis interaktif Miles et al (Miles, M.B; Hubberman, A.M,; Saldana, 2014), disimpulkan bahwa melalui strategi story-telling yang digunakan, para penyuluh selaku pencerita berusaha memposisikan dirinya dengan membawakan cerita yang didasarkan pada penggunaan kisah-kisah dalam sejarah Islam untuk melibatkan target audiens di dalam cerita mereka. Dari struktur narasi yang digunakan, secara umum cerita yang disampaikan melibatkan humor dan mitos dan telah dapat memenuhi koherensi struktural dan karakterologis. Akan tetapi, terdapat beberapa cerita yang belum menunjukkan koherensi material.
\end{abstract}

Kata Kunci: pendewasaan usia perkawinan, strategi komunikasi, storytelling, paradigma naratif

\title{
Pendahuluan
}

Tidak dapat dipungkiri bahwa pernikahan usia anak hadir sebagai agenda pembangunan, bukan hanya dalam lingkup nasional tetapi juga dalam skala global. Dalam agenda SDGs sendiri, penanganan terhadap masalah pernikahan usia anak ini setidaknya dapat mencapai tiga dari 17 poin tujuan yaitu good health and wellbeing, quality education dan gender equality. Dalam konteks Indonesia, berbagai upaya telah dilakukan pemerintah untuk mengurangi terjadinya pernikahan usia anak, meskipun pandangan pesimis muncul ketika melihat payung hukum yang saling bertabrakan. Inayati melalui penelitiannya mengungkapkan bahwa perkawinan di bawah umur terjadi karena besarnya toleransi yang diberikan UU No. 1 Tahun 1974 (Inayati, 2015). Regulasi ini bertentangan dengan UU No. 35 Tahun 2014 tentang Perlindungan Anak. Lebih lanjut penelitian tersebut merekomendasikan perlunya upaya harmonisasi antar berbagai sistem hukum perkawinan yang berlaku di Indonesia. Rekomendasi yang sama diajukan (Reni Kartikawati, 2014) melalui penelitiannya tentang dampak perkawinan anak di Indonesia.

Berbagai penelitian sebelumnya telah dilakukan dengan berfokus pada implementasi program PUP dan kaitannya dengan pengaruh yang dimunculkan pada remaja, seperti dalam penelitian yang dilakukan Ma'arif yang menemukan bahwa meskipun tidak ada hubungan yang signifikan antara tingkat pengetahuan 
Nilam Wardasari, Yun Fitrahyati Laturrakhmi, Azizun Kurnia Illahi:

Strategy Analysis of Storytelling in Communicating Marriage Age Maturity Program in The Society

Analisis Strategi Storytelling Dalam Mengomunikasikan Program Pendewasaan Usia Perkawinan

Pada Masyarakat

dengan sikap remaja terkait PUP, variabel sosial budaya justru memiliki hubungan yang signifikan dengan sikap remaja terkait PUP (Ma'rif, 2018). Ditunjukkan pula oleh penelitian Hasanah et al yang menemukan bahwa terdapat pengaruh yang signifikan antara implementasi substansi Program PUP terhadap pengambilan keputusan menikah usia dini pada remaja di Kecamatan Lemahwungkuk Cirebon (Hasanah, U; Tarma; Jaelani, 2019). Sementara itu, beberapa penelitian lainnya menyoroti aspek sosialisasi dari Program PUP dengan menggarisbawahi pihakpihak yang terlibat antara lain: Pusat Informasi Konseling Remaja (PIK-R) (Wahyuningrum, D.M., Gani, H.A., Ririanty, 2015), pihak sekolah (Rulistyana, 2017), tokoh agama (Aminullah, 2017), maupun melalui konseling teman sebaya (Husnida, N., Halimatussaadiah, 2018).

Dalam konteks keilmuan komunikasi, hal ini secara jelas menunjukkan peranan komunikasi untuk mengubah perilaku sasaran khususnya berkaitan dengan gagasan pembangunan. Mengutip Mefalopulos (Mefalopulos, 2008), dalam fungsi ini komunikasi digunakan untuk menumbuhkan kesadaran atau memberi pengetahuan tentang suatu isu untuk mencapai tujuan yang diharapkan. Dengan kata lain, komunikasi kemudian berposisi sebagai 'an organizational delivery system' (S. Melkote \& Steeves, 2015) yang bertanggung jawab dalam fungsi 'to inform and educate the masses' (S. R. Melkote, 2018). Urgensi dari eksplorasi strategi komunikasi dan edukasi tentang PUP ini adalah berkaitan dengan dimensi keilmuan sekaligus dimensi praktis. Secara keilmuan, penelitian ini menawarkan kebaruan melalui penggunaan narrative paradigm theory yang menekankan pada fungsi storytelling dan berakar dari nilai-nilai lokal yang dapat memengaruhi keyakinan dan tindakan masyarakat. Sementara itu, secara praktis, penelitian ini diharapkan dapat memberikan rekomendasi tentang strategi komunikasi dan edukasi berbasis storytelling yang lebih efektif dan berakar pada nilai-nilai tradisional. Dengan demikian, proses edukasi dan persuasi tentang gagasan pembangunan dapat dijembatani secara lebih efektif melalui storytelling, dibanding melalui communication tools yang mengarah pada logical products seperti yang sudah banyak digunakan dalam sosialisasi program PUP.

\section{Narative Paradigma dan Storytelling - Strategi Narasi Memersuasi Publik}

Secara terminologis, naratif berarti suatu cerita yang terdiri dari sekuel peristiwa dengan urutan kejadian tertentu. Teori ini digagas oleh Walter R Fisher dalam bukunya human Communication as Narration (1987), fisher menyebut jika manusia sebagai makhluk bercerita, yang dapat disimpulkan segala pengalaman dan pemahaman hidup manusia dianggap sebagai narasi yang berlangsung terus menerus, ada konflik, ada karakter orang per orang, ada awal, ada proses, dan ada titik akhirnya (Kriyantono, 2013). Paradigma ini berpendapat proses komunikasi merupakan suatu narasi, dan individu yang terlibat di dalamnya berfungsi sebagai para penyampai dari serangkaian cerita (narasi) itu. Narasi merupakan cara yang digunakan individu untuk memahami lingkungannya (Kriyantono, 2013).

Fisher (1987) dalam (Kriyantono, 2013) menjelaskan beberapa asumsi dasar paradigm narrative, yaitu (a) Manusia secara alamiah adalah "makhluk bercerita", (b) narasi tetap berisi alasan rasional - logis walau mengedepankan sifat internal subjektivitas, (c) Individu memerlukan cara untuk menentukan cerita yang 
bisa dipercaya dan mana yang tidak (good reason), (d)Penilaian tentang good reason di atas sangat ditentukan oleh budaya, karakter, latar belakang, nilai-nilai kepercayaan, pengalaman, ataupun kesukaan masing-masing individu, (e) Proses mengonstruksi narasi dan produk makna bersifat dinamis dan (f) Rasionalitas dari pesan komunikasi sangat ditentukan oleh bagaimana cara seseorang bercerita.

Fisher (1987) konteks persuasi menjelaskan, bahwa teori ini menekankan keefektivan persuasi melalui narasi atau disebut storytelling (Kriyantono, 2013). Menurut teori yang dijelaskan oleh Dainton \& Zelley (2005) narrative paradigm dan storytelling, pesan persuasif yang efektif bukanlah pesan tentang fakta rasional, melainkan lebih kepada pesan narasi yang mampu meyakinkan khalayak tentang "alasan/argument/justifikasi yang baik" (good reason) untuk terlibat dalam suatu tindakan tertentu (Kriyantono, 2013). Dipertegas dalam penelitian Li, et al. (2019) bahwa naratif secara intrinsik persuasif karena mereka menggambarkan pengalaman tertentu daripada kebenaran umum. Narasi tidak perlu membenarkan keakuratan klaim mereka; cerita itu sendiri menunjukkan klaim (Li, Jia; Tang, Jie; Liu, Xuan \& Ma, 2019). Logika narasi lebih dipilih dibandingkan logika tradisional yang digunakan dalam argumentasi. Logika narasi menyatakan bahwa orang menilai kredibilitas melalui apakah ceritanya runtut (melalui koherensi) dan terdengar benar (mempunyai ketepatan) (Sobur, 2014).

\section{Metode Penelitian}

Penelitian ini merupakan penelitian kualitatif. Moleong menyebutkan bahwa penelitian kualitatif dimaksudkan untuk dapat memahami fenomena tentang apa yang dialami oleh subjek penelitian secara langsung, holistik dan dengan cara mendeskripsikan dalam bentuk kata-kata, konteks ilmiah dan memanfaatkan berbagai metode ilmiah pula. Tipe penelitian deskriptif penelitian ini ditujukan untuk mendeskripsikan pola-pola dan strategi komunikasi dan edukasi yang dilakukan penyuluh lapang dalam pendewasaan usia perkawinan hingga dapat merumuskan model strategi komunikasi dan edukasi pendewasaan usia perkawinan berbasis storytelling (Lexy J. Moleong, 2017). Neumann mengemukakan outcome dari descriptive research adalah gambaran detail tentang suatu subjek (Neuman, 2014). Memahami bahwa pernikahan di usia anak hadir sebagai agenda pembangunan yang tidak hanya pada lingkup nasional tetapi juga dalam skala global, peneliti memilih Kabupaten Pasuruan sebagai lokasi riset dengan argumentasi bahwa wilayah ini merupakan satu dari sekian wilayah di Jatim dengan prevalensi pernikahan usia anak yang tinggi, yaitu sebesar 24.26\% (Badan Pusat Statistik Provinsi Jawa Timur, 2017).

Penelitian ini menggunakan paradigma narratif. Fisher dalam Kriyantono menjelaskan beberapa asumsi dasar paradigma narratif, yaitu (a). manusia secara alamiah adalah "makhluk bercerita", (b). narasi tetap berisi alasan rasional - logis walau mengedepankan sifat internal subjektifitas, (c). individu memerlukan cara untuk menentukan cerita yang bisa dipercaya dan yang tidak (good reason), (d). penilaian tentang good reason akan sangat ditentukan oleh budaya, karakter, latar belakang, nilai-nilai kepercayaan, pengalaman atau pun kesukaan masing-masing individu, (e). proses mengkonstruksi narasi dan produk makna bersifat dinamis, (f). 
Nilam Wardasari, Yun Fitrahyati Laturrakhmi, Azizun Kurnia Illahi:

Strategy Analysis of Storytelling in Communicating Marriage Age Maturity Program in The Society

Analisis Strategi Storytelling Dalam Mengomunikasikan Program Pendewasaan Usia Perkawinan

Pada Masyarakat

rasionalitas dari pesan komunikasi sangat ditentukan oleh bagaimana cara seseorang bercerita.

Berdasarkan tujuan khusus yang hendak dicapai dalam penelitian ini, maka informan dari penelitian ini adalah tujuh orang penyuluh lapangan yang terlibat dalam proses komunikasi dan edukasi dalam upaya pendewasaan usia perkawinan, yaitu Penyuluh Agama Islam Fungsional (PAIF) Kantor Kementerian Agama Kabupaten Pasuruan selaku penyuluh lapangan, para penyuluh lapangan di bawah Dinas Keluarga Berencana dan Pemberdayaan Perempuan (KB-PP) Kabupaten Pasuruan dan Muslimat NU Kabupaten Pasuruan. Untuk mencapai tujuan khusus dari penelitian ini, maka digunakan beberapa teknik pengumpulan data yaitu wawancara mendalam dan FGD (Focus Group Discussion).

\section{Hasil Temuan dan Diskusi}

Penelitian ini berangkat dengan menggunakan desain penelitian kualitatif melalui FGD dan wawancara pada berbagai pihak yang berkaitan langsung dengan aktivitas komunikasi dan edukasi tentang Program Pendewasaan Usia Perkawinan untuk merumuskan model komunikasi berbasis story-telling di bawah kerangka narrative paradigm. Melalui kerangka konsep tersebut, penelitian ini mengungkap tiga kategori kunci yang menunjukkan bagaimana strategi story-telling sejauh ini digunakan dalam edukasi tentang pentingnya pendewasaan usia perkawinan, sehingga melalui evaluasi tersebut rekomendasi model story-telling yang lebih sesuai dengan karakteristik target sasaran dapat diajukan. Secara keseluruhan, analisis dilakukan berdasarkan gagasan utama narrative paradigm yang menekankan pada logika narasi, dibanding logika tradisional yang akan jauh berbeda dengan cara pandang aspek persuasif pada retorika klasik.

\section{Mengenali Konteks Masyarakat Sasaran}

Membicarakan tentang proses edukasi untuk mengubah sikap maupun perilaku target sasaran tidak terlepas dari fungsi komunikasi secara instrumental. Dalam fungsi ini, komunikasi berada dalam fungsi memberitahukan dan mengandung muatan persuasif (Mulyana, 2011)Dalam literatur komunikasi, diskusi tentang komunikasi persuasif banyak dilakukan dalam tradisi sosiopsikologis dan berakar dari riset Hovland (Robert T. Craig and Heidi L. Muller, 2007) dengan menekankan pada sisi komunikan melalui eksplorasi terhadap faktor penyebab persuasive (Griffin, 2009).

Berbeda dengan gagasan Hovland yang lebih menekankan pada dimensi psikologis untuk menjelaskan pesan persuasif dari penerima, pembahasan tentang komunikasi persuasif juga sangat banyak dikaitkan dengan tradisi retorika (Robert T. Craig and Heidi L. Muller, 2007) yang juga menunjukkan posisi komunikasi yang dikenal sejak awal sebagai practical art. Di bawah tradisi ini, komunikasi dipandang sebagai “...artful public address" (Griffin, 2009) dengan retorika klasik Aristotle sebagai konsep kunci. Meskipun demikian, alih-alih mengikuti pemikiran retorika klasik, seluruh diskusi dalam penelitian berangkat dari gagasan new rhetoric yang menekankan pada identifikasi. 
Mengutip pendapat Nichols (West, Richard \& Lynn H, 2008), retorika klasik menekankan pada desain yang terencana, sedangkan retorika baru lebih menekankan pada identifikasi- sebuah pertemuan antara pencerita dan audiens. Retorika baru memang digunakan untuk menyebutkan pemikiran Kenneth Burke tentang dramatism (West, Richard \& Lynn H, 2008), namun pemikiran Walter Fisher tentang narrative paradigm juga melukiskan gagasan sentral tentang new rhetoric mengingat pemikirannya turut dipengaruhi kuat oleh Kenneth Burke khususnya dalam memandang bahwa "...stories give meaning to experience, draw people together into communities that 'sanction' their stories and position them in history as a part of humanity " (Wright-St Clair, V., Reid, D., Shaw, S. and Ramsbotham, 2014). Fisher juga menegaskan bahwa "...sometimes these stories teach morals, sometimes they explain a preferred course of action, and sometimes they create identification between the storyteller and the audience" (Allen, 2017).

Mengingat narrative paradigm menekankan pada bagaimana pendengar (audiens) dapat terbujuk melalui cerita dan bagaimana rasionalitas naratif (yang menentukan apakah audiens terbujuk atau tidak) dipengaruhi oleh konteks di mana mereka terikat sebagaimana dikemukakan Fisher (West, Richard \& Lynn H, 2008), maka dalam penelitian ini diperlukan upaya mengenali karakteristik khusus dari konteks sosiokultural audiens yang menjadi sasaran Program PUP. Berdasarkan hasil FGD pada para informan dari Dinas Keluarga Berencana dan Pemberdayaan Perempuan (KBPP) Kabupaten Pasuruan, diperoleh hasil bahwa secara umum masyarakat di wilayah Kabupaten Pasuruan sebagai objek penelitian terbagi ke dalam tiga kelompok: pesisir, pegunungan, dan daerah bawah (mendekati pusat pemerintahan kabupaten). Masyarakat di wilayah pesisir dicirikan oleh kecenderungan tingkat pendidikan rendah, masih sangat teguh memegang tradisi dan nilai-nilai tradisional. Karakteristik tersebut berbeda dengan masyarakat di wilayah pegunungan yang memiliki tingkat pendidikan lebih tinggi, lebih terbuka terhadap perubahan, serta mulai menyadari bahwa banyaknya jumlah anak tidak selalu menguntungkan. Di sisi yang lain, masyarakat daerah bawah yang merupakan wilayah pesantren cenderung melanggengkan praktik pernikahan usia anak (child marriage) karena doktrin agama yang dipahami secara parsial tanpa didialogkan dengan konteks yang ada. Temuan ini konsisten dengan data hasil wawancara dengan para Penyuluh Agama Islam Fungsional (PAIF) sebagai berikut:

"Itu tadi, pengaruhnya adalah pengaruh tradisi, atau adat yang sudah ada, kemudian terkait dengan ekonomi, dan mohon maaf, kalau dari sisi agama pemahaman masyarakat itu kalau sudah umur 16 kan.dikira sudah waktunya untuk membangun rumah tangga. Biasanya seperti itu. Tapi..aa..alhamdulilah dari tahun ke tahun itu sudah berkurang..." (SG, komunikasi personal, 3 September 2020).

"(ketakutan bahwa anaknya tidak laku) Naahhh itu ada, ada. Kalo ditilik dari, kalo dibuat diagram itu yang pesisir mbak. Yang punya imej seperti itu itu daerah pesisir ya Lekok, Nguling, Keraton. Kemudian ditambah lagi daerah timur, kalo digaris lho ya, gondang wetan, kemudian lanjut ke daerah winongan, lumbang, lanjut lagi ke daerah rejoso, baru Grati. Ternyata tingkat pendidikan lebih rendah (fanatik terhadap agama) wooohh banyakkk, banyakkk sekali. Kita berbicara misalkan, Kejayan. Kejayan yang notabenenya banyak pesantren, walaupun tidak sebesar Al-Yasini, walaupun tidak sebesar ponpes Ngalah, itu banyak pesantren-pesantren kecil, di situ juga kalau 
Nilam Wardasari, Yun Fitrahyati Laturrakhmi, Azizun Kurnia Illahi:

Strategy Analysis of Storytelling in Communicating Marriage Age Maturity Program in The Society

Analisis Strategi Storytelling Dalam Mengomunikasikan Program Pendewasaan Usia Perkawinan

Pada Masyarakat

seandainya panjenengan mau ikut turun ke bawah, itu juga banyak gadis-gadis yang dinikahkan siri oleh orang tuanya. masih-masih ada. Tapi sampai dengan hari ini saya belum mendata sih jumlah pastinya berapa. Termasuk di Rembang. Rembang itu juga kecil-kecil sudah dinikahkan." (TF, komunikasi personal, 24 Januari 2020).

Hal tersebut dapat diketahui bahwa kondisi sosiokultural masyarakat Kabupaten Pasuruan yang masih memegang teguh nilai-nilai tradisional di satu sisi, diikuti dengan pemahaman yang tidak utuh terhadap hadits nabi di sisi yang lain, mendorong tumbuh suburnya praktik pernikahan usia dini. Hal ini dikonfirmasi oleh laporan rekapitulasi Pengadilan Agama Pasuruan bahwa dalam kurun waktu 2017-2018 jumlah pemohon dispensasi nikah terus meningkat (Tiap bulan, 2018). Dipaparkan bahwa setiap bulan ada pengajuan dispensasi nikah dari pasangan usia anak yang hampir keseluruhan ajuan pernikahan dini tersebut dikabulkan Pengadilan Agama dengan berbagai pertimbangan (Tiap bulan, 2018). Kondisi ini semakin mempertegas urgensi dari dilakukannya aktivitas komunikasi dan edukasi tentang pendewasaan usia perkawinan, khususnya pada masyarakat di wilayah Kabupaten Pasuruan.

Dalam kaitannya dengan story-telling sebagai upaya mempersuasi audiens sasaran terkait pendewasaan usia perkawinan, karakteristik masyarakat ini dapat menjelaskan lebih jauh apakah approach yang sudah digunakan masing-masing penyuluh telah dapat menunjukkan persinggungan dengan target audiens, atau dengan kata lain telah dapat memunculkan identifikasi. Sebagaimana ditegaskan Fisher melalui narrative paradigm bahwa rasionalitas yang digunakan bukanlah rasionalitas tradisional melainkan rasionalitas naratif. Bahkan secara khusus dalam asumsi ketiga teori yang diajukannya, Fisher (West, Richard \& Lynn H, 2008) mengemukakan bahwa apa yang secara khusus mempengaruhi pilihan audiens untuk terpengaruh ataukah tidak adalah konteks di mana mereka terikat. Dengan demikian, untuk menyusun desain pesan berbasis story-telling yang dianggap persuasif oleh audiens sasaran, maka diperlukan pemahaman tentang konteks yang mengikat audiens sasaran.

\section{Mendalami Peran Penyuluh sebagai Pencerita}

Dasar dari paradigma ini adalah komunikasi kepada publik serta khalayak sebagai partisipannya. Paradigma naratif ini juga mengemukakan keyakinan bahwa manusia sebagai seorang pencerita atau yang disebut homo narrans dan mempertimbangkan akan nilai, emosi dan estetika menjadi dasar keyakinan dan perilaku kita (Putri, I.M., Rosida, 2019). Hal ini dapat diartikan bahwa apabila seseorang menceritakan sebuah narasi kepada orang lain atau khalayak lainnya, akan menjadi efektif apabila pendengar atau khalayaknya memiliki nilai-nilai, emosi atau estetika yang sama dengan penceritanya. Hal inilah yang juga berusaha dibahas pada paradigma naratif ini dalam konsepnya yang bernama rasionalitas naratif. Rasional naratif ini merupakan ukuran yang dipergunakan untuk memberikan penilaian cerita manakah yang diyakini dan cerita mana yang tidak dipedulikan. Konsep rasionalitas naratif ini memiliki metode khusus untuk memberikan nilai dari cerita mana yang dibisa diyakini dan mana yang tidak oleh khalayak. 
Berkaitan dengan penelitian ini, dalam konteks komunikasi dan edukasi Program PUP, para penyuluh lapang berposisi sebagai pencerita dalam upaya mempersuasi masyarakat sasaran yang masih menganggap bahwa pernikahan usia anak merupakan hal yang biasa. Alih-alih memandang sekedar sebagai komunikator, hasil penggalian data di lapangan menunjukkan bahwa para penyuluh lapangan di Kabupaten Pasuruan cenderung menggunakan cerita, yang di dalamnya terdapat tokoh, alur, serta kisah tersendiri untuk meyakinkan target sasaran akan pentingnya pendewasaan usia pernikahan. Temuan dalam penelitian ini juga menunjukkan bahwa hal menarik dari aktivitas komunikasi dan edukasi yang dilakukan di wilayah riset adalah menggunakan bingkai cerita dalam perspektif agama Islam yang juga diselingi dengan kisah aktual yang terjadi dalam kehidupan sehari-hari. Hal ini dilakukan sebab karakteristik masyarakat di wilayah Kabupaten Pasuruan didominasi oleh masyarakat agamis sebagai konsekuensi dari banyaknya pesantren yang ada di Kabupaten Pasuruan. Ditemukan pula bahwa pada beberapa wilayah pegunungan dan pesisir, meskipun tidak di kelilingi oleh pesatren, penggunaan cerita dalam perspektif agama juga dipandang lebih efektif sekalipun kondisi sosiokultural masyarakatnya lebih tradisional.

Karakteristik masyarakat tersebut berdampak pada pihak-pihak yang dilibatkan dalam proses komunikasi dan edukasi tentang Program PUP. Hasil FGD dan wawancara menunjukkan bahwa untuk menyukseskan Program PUP di wilayah Kabupaten Pasuruan, para penyuluh lapang yang dilibatkan bukan hanya dari Dinas Keluarga Berencana dan Pemberdayaan Perempuan (KB-PP) tetapi juga para Penyuluh Agama Islam Fungsional (PAIF) di lingkungan Kementerian Agama Kabupaten Pasuruan serta para kader pada grassroot level yang merupakan anggota Muslimat NU. Dalam praktiknya, hasil wawancara dan FGD pada para penyuluh lapangan menunjukkan bahwa dalam upaya mempersuasi sasarannya, mereka memposisikan diri secara berbeda-beda bergantung pada karakteristik audiens yang dihadapi. Seperti misalnya WY yang lebih menyasar kelompok remaja khususnya santriwati, akan memposisikan dirinya sebagai seorang kakak yang memberikan wejangan kepada adiknya. Sedikit berbeda dengan WY, TF cenderung memposisikan diri sebagai orang tua yang mendidik anak-anaknya tentang dampak negatif dari pernikahan di usia anak. Sementara itu, ketika menghadapi target audiens yang merupakan para orang tua, TF cenderung memposisikan dirinya secara setara yang juga sebagai orang tua seperti halnya target audiens. Posisi yang sama diambil oleh ET dan SG dalam proses komunikasi dan edukasi tentang PUP yang mereka lakukan di wilayah kerja masing-masing.

Pada dasarnya, dalam kerangka narrative paradigm, dikemukakan bahwa setiap orang akan mengambil keputusan tentang cerita mana yang akan diterima dan cerita mana yang akan ditolak berdasakan apa yang masuk akal bagi diri mereka (West, Richard \& Lynn H, 2008). Gagasan tersebut menyiratkan makna bahwa sebuah cerita akan lebih persuasive dibanding lainnya bergantung pada seberapa jauh pencerita akan melibatkan audiens di dalam ceritanya. Dalam kaitannya dengan penelitian ini, hal ini dipengaruhi kuat oleh bagaimana para penyuluh memposisikan dirinya dalam hubungannya dengan target audiens serta sejauh mana cerita yang disampaikannya mampu mendekati apa yang menjadi bagian dari kehidupan sehari-hari target audiens. Temuan dalam penelitian ini menunjukkan 
Nilam Wardasari, Yun Fitrahyati Laturrakhmi, Azizun Kurnia Illahi:

Strategy Analysis of Storytelling in Communicating Marriage Age Maturity Program in The Society

Analisis Strategi Storytelling Dalam Mengomunikasikan Program Pendewasaan Usia Perkawinan

Pada Masyarakat

bahwa cerita yang dibangun para penyuluh lapang ditekankan pada narasi dalam bingkai agama yang sangat dekat dengan apa yang diyakini dan dan menjadi kerangka rujukan bagi target audiens. Sebagaimana ditunjukkan oleh kutipan berikut :

“...Lalu saya juga sering menyampaikan sejarah, bagaimana nabi itu juga memperlakukan istri itu seperti apa. Ya begitu saya hadapkan mereka dengan sebuah sejarah, kemudian saya pertanyakan, siap tidak kita seperti itu? Saya bangun agar mereka berpikir. Nah, begitu saya menceritakan Khodijah dengan nabi seperti ini, karena rumah tangga itu tidak seindah yang dibayangkan. Akhiranya hal-hal yang terkecil semacam nabi ketuk pintu tidak dibuka-bukakan." (WY, Komunikasi Personal, pengumpulan data tanggal 9 September 2020).

"...saya menyampaikan cerita-cerita tentang perempuan-perempuan hebat. Perempuan hebat seperti Khodijah itu ya seorang istri, tetapi dia juga niagawan bahkan eksportir, perempuan itu Islam. Nah kita ini Islam, apa bisa mendidik anak di rumah tetapi tidak menghilangkan pada sektor-sektor ekonomi. Sama juga misalnya pada sisi politik, saya menampilkan Ratu Bilqis. Ratu Bilqis itu perempuan, tapi dia diberi wewenang oleh Raja Sulaiman agar dia bisa memimpin rakyat daerahnya. Dia itu perempuan juga ngurus anak juga ada di dapur dan sebagainya, tetapi dia dalam dunia politik mampu." (WY, Komunikasi Personal, pengumpulan data tanggal 6 September 2020).

Melalui kedua kutipan tersebut terlihat upaya informan yang dalam hal ini adalah penyuluh lapangan berupaya untuk menyatukan target audiens dalam satu komunitas cerita tertentu dan akan memposisikan mereka pada sejarah yang juga akan menjadi bagian dari nilai kehidupan mereka. Hal ini sejalan dengan pernyataan Fisher yang dikutip oleh (Wright-St Clair, V., Reid, D., Shaw, S. and Ramsbotham, 2014) menjelaskan bahwa "As a master metaphor, narration subsumes the other proposed models of human rationality. Relying on Kenneth Burke, Fisher noted that stories give meaning to experience, draw people together into communities that "sanction" their stories and position them in history as a part of humanity. Sementara itu, posisi yang diambil yang cenderung berbentuk symmetrical relationship dibanding asymmetrical relationship menjadi faktor pendukung dalam proses penceritaan. Penggunaan Khodijah dan tokoh-tokoh lain dalam sejarah Islam digunakan untuk memperkuat karakter-karakter dalam cerita yang dapat dipercaya. Hal ini merujuk pada apa yang disebut Fisher (West \& Turner, 2019) sebagai koherensi karakterologis.

Dalam upaya menggunakan cerita dan narasi untuk mempersuasi target audiens, terdapat kondisi-kondisi ketika narasi yang dibangun mendatangkan perdebatan dari target audiens. Kondisi ini menggambarkan pemikiran Fisher sebagai eksplorasi terhadap pendapat Angel Medina dan menemukan bahwa paradigma naratif ini memberikan peluang atau tempat kepada masyarakat dalam perdebatan dan menceritakan kembali narasi (Wright-St Clair, V., Reid, D., Shaw, S. and Ramsbotham, 2014). Berikut kutipan wawancara yang menunjukkan perdebatan dalam cerita: 
"ada pemikiran dari masyarakat bahwa lebih baik menjanda di usia muda, dari pada belum menikah di usia 20 tahun ke atas. Jadi masyarakat itu mikirnya, lek anakku gak rabi-rabi lak dipikir gak payu”. (TF, Komunikasi Personal, pengumpulan data tgl 7 september 2020)

"Masyarakat masih rawan (gampang tersinggung) karena adanya budaya yang masih kental mempengaruhi pola pikir masyarakat, misalnya perempuan umur 20 tahun belum menikah itu disebut perawan tua." (WY, Komunikasi Personal, pengumpulan data tgl 7 september 2020).

“...pernah terdapat beberapa kelompok masyarakat yang menggunakan pernikahan Rasul sebagai alasan atau dasar melakukan pernikahan dini. Sehingga TF memberikan pengarahan dasi sisi perbedaan yang mendasar dari waktu, situasi dan kondisi perempuan Arab dan Jawa.... Fanatisme agama pada daerah dengan banyak pondok pesantren yang kecil dengan pemikiran yang tradisional" (TF, Komunikasi Personal, pengumpulan data 24 Januari 2020).

Merespon perdebatan tersebut, para penyuluh lapangan kembali menggunakan cerita dengan menekankan pentingnya konteks dengan cara memasuki pengalaman keseharian target audiens sehingga cerita yang disajikan pada akhirnya dapat menunjukkan keterkaitan dengan apa yang dipahami dan dijalani target audiens dalam kehidupan kesehariannya.

Melalui pemaparan data tersebut, semakin jelas bahwa bagaimana cerita digunakan juga bergantung pula pada bagaimana para penyuluh selaku pencerita membawa cerita untuk masuk ke dalam kehidupan sehari-hari target audiens sehingga akan bisa mempersuasi target audiens untuk mengubah pemikiran mereka tentang batas usia pernikahan. Hal ini mampu menggambarkan pendapat Charles Larson yang sejalan dengan Fisher bahwa paradigma naratif ini tidak dapat lepas dari tindakan persuasive yang dilakukan pada saat proses komunikasi berlangsung. Larson "At the core of this perspective is the belief that the drama or story is the most powerful and pervasive metaphor that humans can use to persuade and explain events "(Larson, 2007).

\section{Mengungkap Strategi Membangun Narasi}

Penerapan narasi dapat mendorong perubahan dalam perilaku (Hinyard, Leslie J; Matthew, 2007) sehingga tergolong dalam pesan persuasif. Menurut Dainton \& Zelley dalam Kriyantono menjelaskan teori narrative paradigm dan storytelling, pesan persuasif yang efektif bukanlah pesan tentang fakta rasional, melainkan lebih kepada pesan narasi yang mampu meyakinkan khalayak tentang "alasan/argument/justifikasi yang baik" (good reason) untuk terlibat dalam suatu tindakan tertentu (Kriyantono, 2013). Dipertegas dalam penelitian (Li, Jia; Tang, Jie; Liu, Xuan \& Ma, 2019) bahwa naratif secara intrinsik persuasif karena mereka menggambarkan pengalaman tertentu daripada kebenaran umum. Narasi tidak perlu membenarkan keakuratan klaim mereka; cerita itu sendiri menunjukkan klaim (Dahlstrom, Michael F \& Ho, 2012). West dan Turner menyebutkan bahwa logika narasi lebih dipilih dibandingkan logika tradisional yang digunakan dalam argumentasi. Logika narasi menyatakan bahwa orang menilai kredibilitas melalui 
Nilam Wardasari, Yun Fitrahyati Laturrakhmi, Azizun Kurnia Illahi:

Strategy Analysis of Storytelling in Communicating Marriage Age Maturity Program in The Society

Analisis Strategi Storytelling Dalam Mengomunikasikan Program Pendewasaan Usia Perkawinan

Pada Masyarakat

apakah ceritanya runtut (melalui koherensi) dan terdengar benar (mempunyai ketepatan) (Sobur, 2014). Sehingga dapat disimpulkan jika dalam penyampaian pesan narasi, "stategi isi pesan" menjadi fokus perhatian utama agar pesan dapat sampai dan diterima dengan baik oleh audiensnya. Dalam penelitian ini, penyuluh mempunyai stratgei narasi khusus yang dirancang sedemikian rupa disesuaikan dengan karakter audiens dan konteks budaya yang ada di daerah setempat.

Temuan penelitian menunjukkan jika penyuluh sebagai informan menggunakan strategi pesan yang berisi cerita/ pengalaman seseorang / tokoh dalam menjalin rumah tangga di usia pernikahan dini yang disertai dengan konflik yang muncul sehingga terlihat dampak konflik tersebut. Penyuluhan yang dilakukan juga secara lisan sebagaimana salah satu media menyampaian pesan narasi. Hal ini seusai dengan konsep narasi dari Dahlstrom \& Ho, narasi merupakan komunikasi apa pun yang menggambarkan pengalaman spesifik karakter dari waktu ke waktu, dengan memperhatikan bahwa format yang paling sering dalam konteks berupa teks atau pidato. Berikut isi pesan dalam memberikan penyuluhan (Dahlstrom, Michael F \& Ho, 2012):

"Apakah sebagai perempuan harus sekedar di rumah kemudian hanya ngurus anak saja. Hal-hal yang kita pancing semacam itu kemudian akhirnya bisa terpancing, dan mereka itu kalau di prosentase belum merata semuanya. Tetapi di antara mereka sudah banyak yang berpikir, ternyata rumah tangga itu gak sak karepe dewe. Gak semaunya, yang terus wis poko e ketemu laki-laki dan perempuan. Karena di sana itu pernah ada, jadi nikah dini yang usianya masih belum pas sama undangundang pernikahan laki-laki dan perempuan itu 19 tahun. Nah, sebelum usia itu mereka sudah dinikahkan secara siri. Kemudian karena siri, dia tidak bisa mendapatkan legalitas dari KUA. Untuk bisa mendapatkan legalitas ini, dia masih menunggu beberapa tahun lagi. Ternyata untuk menunggu untuk beberapa tahun lagi itu sudah gak asik lagi, mereka ke KUA itu pakai kaos oblong, sudah gak pake baku pengantin, kemudian perempuannya ya seperti itu sudah tidak menarik lagi. Bahkan kepala KUA itu bilang, moshok pernikahan dini hal yang sangat tidak menarik ini. Juga ada kasus di KUA, ada anak laki-laki dan perempuan itu mau dinikahkan, lah antara mereka itu tidak saling kenal dan tidak saling tahu, sama kepala KUA itu sampai disindir, ini zaman udah canggih sekali, untuk mengetahui orang dimana pun sangat mudah, coba sekarang kenalan dulu deh sama calon suami sama calon istri. Jangan sampai saling tidak kenal langsung dinikahkan, jadi istilahnya kenalan atau taaruf itu melihat bagaimana kapasitas kita bobot, bebet, dan bibitnya itu seperti apa. Dalam rangka semacam itu jangan sampai KUA menyarankan mereka untuk mengenal. Jadi yang kami sampaikan dengan penyuluhan itu ya begitu. Kita menggugah mereka-mereka itu tentunya di kalangankalangan perempuan agar mereka siap tidak sih dengan sebuah pahit dari rumah tangga itu apa sudah siap betul. Karena rumah tangga itu ya tadi sangat berat, sebuah perjanjian agung seperti perjanjian para nabi kepada para Tuhan-nya itu tidak mudah. Kalau hanya sekedar melihat sepasang saja, apalagi melihat manten anyar yo seneng-seneng ae. Untuk melanjutkan syiar agama dan sebagainya itu tidak mudah, itu yang harus dipikir. Kalau mereka sudah berpikir, setidaknya kita ini sudah ada semacam keberhasilan entah itu berapa persen. Gitu Mbak Nilam." (WY, komunikasi personal, tanggal 6 September 2020, bergaris bawah merupakan focus pada storytelling). 
Dalam kutipan isi pesan di atas terlihat jika penyuluh menggunakan strategi narasi dengan menceritakan contoh kasus yang pernah terjadi sebelumnya secara runtut alur peristiwa yang terjadi melibatkan pengalaman orang lain yang hendak melakukan pernikahan dini, dalam contoh kasus tersebut juga disebutkan dampak yang timbul jika pernikahan dini dilakukan. Strategi yang sama juga terlihat informan lain selaku penyuluh yang juga mengandalkan contoh kasus sebagai isi pesan cerita saat memberikan penyuluhan.

"Langsung dikasih contoh, "Jadi iki contohnya, iku selingkuh, anak e gak karukaruan, iki cerai, kaya tadi stunting, opo seperti itu yang sampean inginkan? Opo anak-anak seperti itu yang sampean inginkan" atau terlalu bapak-bapak, ibu-ibunya yang terlalu menganggap anaknya sing ciliki, atau marganya. "Kan masih cilik bu jadi saya atur", "Loh kalo masih kecil ojok dinikah no." jadi gitu. Jadi artinya menyerahkan sepenuhnya, perwaliannya, kepada suaminya. Kalo sudah ke suaminya, "Lah aku melok, urus no. Iki kudu ngene, di omah kudu ngene, harus kudu ngene, kudu ngene.", "Salaaah" saya gitukan. Jadi ya banyak, banyaklah." (TF, penyuluh agama PNS, komunikasi personal tanggal 7 September 2020, bergaris bawah merupakan focus pada storytelling).

"Yo pokoe sing jelas kalau kita menjalankan tugas kita dengan baik, meskipun orang gak minta itu kalau ada masalah, malah kita kadang jemput bola. Terus adakan kasus di sini itu pernikahan dini belum cukup umur, terus kemudian KDRT, itu juga kita buat contoh juga. Saya ceritakan gimana awalnya mereka maksa untuk dini, sudah diwanti wanti tetap saja nikah dini, orang tuanya ngenyel. Alhirnya datang lagi ke saya lagi, ternyata masalah KDRT.Itu saya jadikan contoh tak ceritakan detail biar mereka tau kebanyakan yang nikah diri gimana. Jadi kalau ada kasus terjadi pernikahan dini itu kita juga ikut membantu menyelesaikan, membantu mencari solusi. Misalkan gak mempan, ya kita panggil kyai apa gimana gitu." (ED, penyuluh agama non PNS, komunikasi personal tanggal 2 September 2020, bergaris bawah merupakan focus pada storytelling)

"Kalau ditanya kesiapan biasanya saya tanya "kamu sudah siap belum?" mereka jawabnya "siap" tapi, saya lihat dari jawabannya itu ada sedikit jawaban yang mungkin keterpaksaan. Dalam artian begini, satu, bisa juga muncul dari factor tuntutan orang tua. Misalnya si laki-laki belum bekerja, si perempuan sudah bekerja. Tapi ini sudah sering jalan-jalan bareng, kemudian orang tua juga sudah saling mengenal, sehingga mau gak mau orang tua itu menuntuk anak itu untuk segera menikah. Sehingga laki-lakinya ada omongan tidak siap. Kalau pun dia siap, itu pasti ada rasa keterpaksaan untuk menjalani itu semua. Karena memang sebenarnya laki-laki kalau ditanya siap atau tidak siap, rata-rata dari segi ekonomi, kemudian temen-temen yang belum punya pekerjaan tetap seperti itu. Sehingga kemudian saya kalau memang itu sudah, administrasi masuk ke KUA, dari orang tua juga sudah menentukan harinya, maka saya sarankan sudahlah, kalau memang dari segi umur yakita bismillah saja, kita niatkan saja ingin ibadan untuk membentuk sebuah keluarga yang diridhoi oleh Allah. Tapi itu tentu kalau memang usianya sudah siap. Baik dari sisi Undang-undang maupun psikologis. Tapi kalau usianya memang masih belia, katakanlah usia masih 17 tahun, saya arahkan untuk berfikir kembali..." (SG, penyuluh agama PNS, komunikasi personal tanggal 3 September 2020, bergaris bawah merupakan focus pada storytelling). 
Nilam Wardasari, Yun Fitrahyati Laturrakhmi, Azizun Kurnia Illahi:

Strategy Analysis of Storytelling in Communicating Marriage Age Maturity Program in The Society

Analisis Strategi Storytelling Dalam Mengomunikasikan Program Pendewasaan Usia Perkawinan Pada Masyarakat

Sebaliknya, beberapa informan terlihat dalam teks di atas tidak menceritakan secara runtut sebuah peristiwa dengan baik, karakter tokoh yang diceritakan juga tidak disampaikan dengan detail selayaknya logika narasi, di mana logika narasi menyatakan bahwa orang menilai kredibilitas melalui apakah ceritanya runtut (melalui koherensi) dan terdengar benar (mempunyai ketepatan) (Sobur, 2014). Jika cerita yang disampaikan dengan menggunakan strategi kejelasan dan keruntutan terkait peristiwa yang meliputi (alur peristiwa, karakteristik tokoh, ketepatan konteks dan waktu) dapat disampailan dengan baik dalam cerita maka kemungkinan dinilai cerita tersebuh koheren dan dianggap benar oleh audiens sehingga dapat mempersuasi. Fisher mengatakan manusia lebih dapat terbujuk oleh sebuah cerita yang bagus dibandingkan oleh argumen yang baik. Ia juga menyatakan bahwa,"Cerita memengaruhi kita, menggerakkan kita, dan membentuk dasar untuk keyakinan dan tindakan kita." (West \& Turner, 2019). Menurut Fisher, cerita yang bagus adalah cerita yang ampuh dalam persuasi (Gilovich \& Griffin, 2012). Bagaimana pengemasan sebuah cerita yang ingin disampaikan dapat menjadi sebuah pengaruh dalam pembentukkan persepsi di benak individu yang mendengarnya, lalu mempersuasi, dan pada akhirnya dapat pula menentukan perilaku, perubahan, serta pengambilan keputusan seseorang untuk mendukung atau mungkin menolak isi dari tujuan disampaikannya cerita tersebut (Sobur, 2014).

Schank dan Berman (2002) dalam (Hinyard, Leslie J; Matthew, 2007) mengidentifikasi lima jenis cerita tertentu, masing-masing digunakan untuk tujuan komunikasi yang berbeda: cerita resmi dibuat untuk menceritakan sebuah versi kejadian yang tidak berbahaya atau posisi kelompok, menciptakan cerita yang dibuat up atau fiksi, cerita pengalaman langsung, cerita tangan kedua orang lain yang kita menceritakan kembali, dan kisah-kisah umum secara budaya yang digeneralisasikan dan meresap dalam suatu budaya lingkungan hidup. Komunikasi naratif melibatkan penggunaan salah satu jenis cerita in untuk menyampaikan suatu poin kepada pihak lain atau untuk menerima informasi dari pihak lain (Hinyard, Leslie J; Matthew, 2007). Jika merujuk kembali pada temuan penelitian, maka kecenderungan jenis cerita yang digunakan oleh para penyuluh berupa menceritakan kembali pengalaman orang lain dan menceritakan kisah kisah tokoh yang dianggap panutan. Berikut contoh isi pesannya:

"Ya, kalau saya dalam menyampaikan penyuluhan tentu harus berlandaskan dalil. Jadi sebetulnya dalam keluarga sakinnah. Keluarga itu di contohkan dalil tentang sakinnah mawadah warohmah dalam Al-Quran itu seperti apa. Lalu saya juga sering menyampaikan sejarah, bagaimana nabi itu juga memperlakukan istri itu seperti apa. Ya begitu saya hadapkan mereka dengan sebuah sejarah, kemudian saya pertanyakan, siap tidak kita seperti itu? Saya bangun agar mereka berpikir. Nah, begitu saya menceritakan khodijah dengan nabi seperti ini, karena rumah tangga itu tidak seindah yang dibayangkan. Akhirnya hal-hal yang terkecil semacam nabi ketuk pintu tidak dibuka-bukakan."

(WY, penyuluh agama PNS, komunikasi personal tanggal 9 September 2020, bergaris bawah merupakan focus pada storytelling) 


\begin{abstract}
"Sebelum menuju generasi yang baik dan tidak baik, maka orang tua harus menjadi teladan, figur pendidik pemula dan utama. Sehingga para calon-calon pengantin itu sedikit berpikir, seperti saya harus belajar, saya harus mempersiapkan keterampilan, psikologis, dan sebagainya. Begitu juga ketika saya menyampaikan cerita-cerita tentang perempuan-perempuan hebat. Perempuan hebat seperti khodijah itu ya seorang istri, tetapi dia juga niagawan bahkan eksportir, peremuan itu islam. Nah, kita ini islam, apa bisa mendidik anak di rumah tetepi tidak menghilangkan pada sektor-sektor ekonomi. Sama juga misalnya, pada sisi politik, saya menampilkan Ratu Bilqis. Ratu itu perempuan, tapi dia diberi wewenang oleh Raja Sulaiman agar dia bisa memimpin rakyat daerahnya. Dia itu peremuan juga ngurus anak, juga ada di dapur dan sebagainya, tetapi dia dalam dunia politik mampu." (WY, penyuluh agama PNS, komunikasi personal tanggal 6 September 2020, bergaris bawah merupakan focus pada storytelling)
\end{abstract}

Strategi isi pesan di atas menunjukkan jika penyuluh menggunakan contoh kasus tokoh yang menjadi panutan seperti Nabi Muhammad, khotidjah dan Ratu Bilqis dalam bercerita. Strategi narasi tersebut di satu sisi menjadi strategi yang efektif karena disesuaikan dengan karakteristik audiens yang kebetulan adalah santri. Di sisi lain ditemukan kejanggalan jika merujuk pada konsep narasi sebagai peristiwa dalam garis waktu. Ricoeur (1984) dalam Sobur (2014) melihat ketidakterpisahan antara konsep narasi dan perbincangan tentang waktu. Narasi dan waktu saling menentukan secara timbal balik. Apakah peristiwa dalam narasi sesuai dengan konteks dan waktu saat penyuluh bernarasi? Hal tersebut menimbulkan pertanyaan bagi peneliti, karena sangat dibedakan antara waktu peristiwa dengan waktu penceritaan (Sobur, 2014). Waktu peristiwa waktu ketika peristiwa yang diceritakan dalam narasi terjadi. Sedangkan waktu penceritaan ketika penyuluh tersebut memberikan narasinya dalam penyuluhan, sehingga konteks menjadi hal penting ketika memilih isi pesan dalam narasi. Hal ini semakin diperkuat jika narasi mewakili representasi mental yang berfokus pada pemahaman orang dan tindakan mereka di mana makna tertanam dalam konteks cerita. Unit informasi tidak dapat dihapus dan dikomunikasikan secara terpisah karena informasi naratif bergantung pada konteks untuk maknanya (Dahlstrom, Michael F \& Ho, 2012).

Dalam penelitian ini juga ditemukan strategi narasi berupa permainan Bahasa dengan menggunakan humor. Sobur (2014) menyebutkan jika salah satu permainan Bahasa yang dapat digunakan dalam narasi adalah pelesatan Bahasa yang salah satunya termasuk humor. Humor terlihat dalam beberapa informan penyuluh saat memberikan penyuluhan.

"Ya sebenarnya ada hasilnya juga sih seperti gini termasuk mendidik ini salah satu tema saya ya. Mendidik anak dengan sayang, terus saya contohkan biasanya di jaamah itu, di majelis taklim itu ibu-ibu kan membawa anak, lah terus kalau ada anak dia nakal terus dikerengi, saya gitu itu saya contohkan itu cara mendidik anak dengan kasih sayang adalah begini begini, jadi kalau misalkan ada anak nakal jangan diseneni atau dikerengi, ojo malah diceplesi, itu arek e malah nakal gitu. Lek anak nakal itu biasa, lek ibu nakal itu baru boleh diceplesi, malah saya gitu. Jadi Bahasa saya dengan guyonan Mbak Nilam." (ED, penyuluh agama non PNS, komunikasi personal tanggal 2 September 2020, bergaris bawah merupakan focus pada storytelling) 
Nilam Wardasari, Yun Fitrahyati Laturrakhmi, Azizun Kurnia Illahi:

Strategy Analysis of Storytelling in Communicating Marriage Age Maturity Program in The Society

Analisis Strategi Storytelling Dalam Mengomunikasikan Program Pendewasaan Usia Perkawinan

Pada Masyarakat

Selain strategi permainan Bahasa melalui humor, mitos sering juga digunakan oleh penyuluh sebagai contoh kasus saat bernarasi. Mitos sebagai narasi awal sebuah kebudayaan (Sobur, 2014) menunjukkan jika di dalam daerah tertentu mitos berperan kuat untuk membentuk kebudayaan pada daerah tersebut. Temuan penelitian menunjukkan jika mitos masih kuat menggiring pemikiran dan perilaku masyarakat Pasuruan dalam memahami pernikahan di usia dini. Sehingga Penyuluh membuat strategi narasi condong memerangi mitos yang dirasa memang berdampak tidak baik khususnya bagi pemahaman dan perilaku pernikahan usia dini.

"Kemudian saya juga ceritakan yang ada di rumah tangga itu isi-isinya apa saja. Mendidik anak itu super-supernya bukan main, tidak seperti yang teori katakana. Yang kita rasa itu luar biasa dan bahkan mungkin bisa jadi tidak kita duga. Juga misalkan kadang-kadang persoalan-persoalan yang sangat kecil itu saya sampaikan. Kadangkadang pengalaman yang kita alami ibu rumah tangga itu kita sampaikan, tidak seindah yang sampeyan duga. Senang antara laki-laki dengna perempuan kemudian menikah itu memerlukan pondasi yang banyak untuk memberlangsungkan rumah tangga itu langgeng terutama sakinnah mawaddah warohmah. Sangat banyak sekali terutama dari sisi ekonomi, seperti sudah siapkah ekonomi dalam membangun rumah tangga. Jika sudah menyinggung ekonomi, tentu akan berpikir kembali. Satu-satunya yang bisa kita bangun ekonomi itu melalui sains atau pengetahuan dan keterampilan, tanpa itu tidak bisa. Belum lagi di dalam rumah tangga itu kita memiliki generasi, apakah anda siapa apakah generasi itu baik dan tidak baik. Sebelum menuju generasi yang baik dan tidak baik, maka orang tua harus menjadi teladan." (WY, penyuluh agama PNS, komunikasi personal tanggal 6 September 2020)

Kutipan di atas menjelaskan bahwa beberapa mitos yang dipercaya oleh masyarakat tidak sepenuhnya benar, sehingga penyuluh menggunakan strategi penjelasan dampak dampak negatif yang kemudian akan muncul hanya karena memercayai mitos. Strategi seperti itu akan jauh lebih mempersuasi ketika penyuluh juga memasukkan unsur penting dalam strategi narasi berupa contoh kasus yang terdiri dari plot (alur cerita), karakter, dan setting. Tentu pemilihannya disesuaikan dengan karakteristik audiens.

"Sehingga pendekatan kita, kesiapan-kesiapan khusus kita kepada santri dengan kepada siswa atau kepada jaamaah yang lain itu berbeda... Kalau kepada santri, kita lebih menekankan bahwa nanti yang Namanya rumah tangga kita harus siap yang namanya mental, kemudian siap menjadi pendidik, siap persoalan apa pun terutama persoalan ekonomi, karena meskipun perempuan itu mereka tidak menutup kemungkinan hal-hal yang bersifat membangun ekonomi. Kalau kepada siswa kita lebih menekankan bahwa menikah itu hanya berumur dan pokoknya senang... karena sangat berkaitan erat sama pernikahan dini dan perceraian. Itu pendekatannya begitu ... kalau kepada PKK, kepada majelis taklim kita mungkin hampir sama bahwa rumah itu menjadi hal yang paling utama. Dalam setiap persoalan apapun, rumah harus menjadi basecamp segalanya. Baik dari pendidikan, ekonomi, diskusi apalah dengan keluarga di rumah itu harus diketahui sejak dini untuk kemudian bisa sama-sama langgeng dalam sebuah pernikahan itu mereka harus terus belajar. Karena jika tidak belajar, maka dia akan macet dalam rumus kehidupan. Artinya, kalau dia sudah tidak mau belajar lagi meskipun rumah tangga, maka yang terjadi itu lagi, cekcok-cekcok dan sebagainya. Soalnya disana itu kita jumpai usia 30 sudah menjanda tiga kali. Nah, ini sangat kita sayangkan, secara ekonomi dia yang pegawai negeri, kemudian latar 
belakang pendidikan juga bagus. Sebetulnya apasih? Sebetulnya hanya persoalan psikologis saja yang masih belum mereka siapkan. Kalau bersama ibu-ibu, kita hanya menyiapkan itu saja. Jadi kita harus belajar secara emosional, kemudian olah rasa agar semuanya terkendali." (WY, penyuluh agama PNS, komunikasi personal tanggal 6 September 2020, bergaris bawah merupakan focus pada storytelling).

Dalam kutipan narasi di atas, tersirat jika penyuluh mempunyai strategi yang berbeda ketika menyasar audiens yang berbeda pula. Hal tersebut bertujuan agar audiens dapat menerima isi pesan narasi dengan baik dan dapat terinternalisasi di dalam diri audiens sehingga memengaruhi sikap dan perilaku audiens. Bruner semakin mempertegas bahwa narasi secara aktif menciptakan makna implisit daripada eksplisit dan menggambarkan realitas melalui pandangan subjektif dari karakter daripada sebagai kepastian objektif (Dahlstrom, Michael F \& Ho, 2012). Mink (1978) juga menjelaskan bahwa di dalam narasi "apa yang membuat sebuah cerita bagus berbeda dengan apa, membuatnya benar" (Dahlstrom, Michael F \& Ho, 2012), Kreiswirth menyebutkan sehingga narasi yang salah jarang dipengaruhi oleh bukti dan sebaliknya membutuhkan narasi yang lebih meyakinkan untuk dilawan (Dahlstrom, Michael F \& Ho, 2012).

\section{Simpulan}

Penelitian ini pada kesimpulan penting yaitu melalui strategi story-telling yang digunakan, para penyuluh selaku pencerita berusaha memposisikan dirinya dengan membawakan cerita yang didasarkan pada penggunaan kisah-kisah dalam sejarah Islam untuk melibatkan target audiens di dalam cerita mereka. Penggunaan strategi ini disesuaikan dengan karakteristik target audiens yang meskipun masih memegang teguh nilai tradisional, cara pandang mereka juga sangat dipengaruhi kuat oleh nilai-nilai agama. Dari sisi struktur narasi, ditemukan bahwa cerita yang disampaikan telah memenuhi koherensi struktural dengan elemen-elemen cerita mengalir dengan lancar. Meskipun demikian, tidak semua cerita telah memenuhi koherensi material yang ditunjukkan oleh belum adanya kongruensi antara penceritaan kisah nabi dengan cerita tentang konteks saat ini. Akan tetapi, dalam hal penggunaan karakter, strategi penceritaan yang digunakan telah memenuhi koherensi karakterologis. Secara keseluruhan, dalam proses penceritaan, telah digunakan berbagai permainan bahasa seperti humor dan mitos untuk dapat lebih mempersuasi target audiens pada pentingnya pendewasaan usia perkawinan.

\section{Ucapan Terima Kasih}

Terima kasih penulis ucapkan kepada pihak-pihak yang telah membantu terselesaikan penelitian ini, di antaranya adalah Penyuluh Agama Islam Fungsional (PAIF) Kabupaten Pasuruan, PLKB yang merupakan penyuluh lapangan di bawah Dinas Keluarga Berencana dan Pemberdayaan Perempuan (KB-PP) Kabupaten Pasuruan dan Muslimat PC-NU Kabupaten Pasuruan serta LPPM Universitas Brawijaya yang telah mendukung tim sehingga terlaksana penelitian dan penulisan artikel ini. 
Nilam Wardasari, Yun Fitrahyati Laturrakhmi, Azizun Kurnia Illahi:

Strategy Analysis of Storytelling in Communicating Marriage Age Maturity Program in The Society

Analisis Strategi Storytelling Dalam Mengomunikasikan Program Pendewasaan Usia Perkawinan

Pada Masyarakat

\section{Daftar Pustaka}

Allen, M. (2017). Communication Research Methods. Sage Publications.

Aminullah. (2017). Upaya pendewasaan usia perkawinan (analisis pandangan tokoh agama terhadap program pendewasaan usia perkawinan (PUP) badan Kependudukan dan Keluarga Berencana Nasional (BKKBN) wilayah D.I. Yogyakarta. Universitas Islam Negeri Sunan Kalijaga.

Badan Pusat Statistik Provinsi Jawa Timur. (2017). Persentase Perempuan Jawa Timur Usia 10 Tahun Ke Atas yang Kawin di Bawah Umur (Kurang dari 17 Tahun) menurut Kabupaten/Kota, 2009-2016. BPS Provinsi Jawa Timur (Statistics Jawa Timur).

Dahlstrom, Michael F \& Ho, S. S. (2012). Ethical Considerations of Using Narrative to Communicate Science. Sage Publication: Science Communication, 34(5), 592-617.

Gilovich, T., \& Griffin, D. (2012). Introduction - Heuristics and Biases: Then and Now. In Heuristics and Biases. https://doi.org/10.1017/cbo9780511808098.002

Griffin, jill. (2009). Customer loyalty: how to learn it, how to keep it. Erlangga.

Hasanah, U; Tarma; Jaelani, M. W. (2019). Pengaruh Implementasi Substansi Program Pendewasaan Usia Perkawinan (PUP) terhadap Pengambilan Keputusan Menikah di Usia Dini pada Remaja. Jurnal Kesejahteraaan Keluarga Dan Pendidikan, 6(2).

Hinyard, Leslie J; Matthew, W. K. (2007). Using Narrative Communication as a Tool for Health Behavior Change: A Conceptual, Theoretical, and Empirical Overview. Sage Journal: Health Education \& Behavior, 34(5), 777-792. https://doi.org/10.1177/1090198106291963

Husnida, N., Halimatussaadiah, M. (2018). Efektivitas sosialisasi konseling sebaya terhadap pengetahuan pendewasaan usia perkawinan (PUP) di Kelurahan Rangkasbitung Barat Kecamatan Rangkasbitung Kabupaten Lebak. Jurnal Medikes, 5(2), 120-131.

Inayati, I. N. (2015). Perkawinan Anak di Bawah Umur dalam Perspektif Hukum, HAM dan Kesehatan. Jurnal Bidan " Midwife Journal ", 1(2), 46-53. https://media.neliti.com/media/publications/234071-perkawinan-anak-dibawah-umur-dalam-pers-ed3d3e52.pdf

Kriyantono, R. (2013). Teori Public Relations Perspektif Barat Dan Lokal. Kencana Prenada Media Group.

Larson, C. U. (2007). Persuasion: Reception and Responsibility. Wadsworth.

Lexy J. Moleong, D. M. . (2017). Metode Penelitian Kualitatif (Edisi Revisi). Rosda.

Li, Jia; Tang, Jie; Liu, Xuan \& Ma, L. (2019). How do users adopt health information from social media? The narrative paradigm perspective. Sage Journal: Health Information Management JournalHealth Information Management Journal, 48(3), 116-126.

Ma'rif, F. (2018). Hubungan antara tingkat pengetahuan dan sosial budaya dengan sikap remaja terkait pendewasaan usia perkawinan. Jurnal Biometrika Dan Kependudukan, 7(1), 39-48. 
Mefalopulos, P. (2008). Development communication Sourcebook: broadening the boundaries of communication. The World Bank. https://doi.org/10.1596/978-0-8213-7522-8

Melkote, S. R. (2018). Communication for development and social change: an introduction. Journal of Multicultural Discourses, 13(2), 77-86. https://doi.org/10.1080/17447143.2018.1491585

Melkote, S., \& Steeves, H. L. (2015). Place and role of development communication in directed social change: a review of the field. Journal of Multicultural Discourses, 10(3), 385-402. https://doi.org/10.1080/17447143.2015.1050030

Miles, M.B; Hubberman, A.M; Saldana, J. (2014). Qualitative data analysis, a method sourcebook, edition 3. Sage Publications.

Mulyana, D. (2011). Ilmu Komunikasi: Suatu Pengantar. PT. Rosdakarya.

Neuman, W. L. (2014). Social Research Methods Qualitative And Quantitative Approaches. Pearson.

Putri, I.M., Rosida, L. (2019). Peningkatan Pengetahuan Program Pendewasaan Usia Perkawinan di Karang Taruna Angkatan Muda Salakan Bantul, Yogyakarta. Jurnal Pengabdian Masyarakat Kebidanan, 1(1), 5-11.

Reni Kartikawati, D. (2014). Dampak Perkawinan Anak di Indonesia. Jurnal Studi Pemuda, 3(1), 2-16. https://doi.org/https://doi.org/10.22146/studipemudaugm.32033

Robert T. Craig and Heidi L. Muller. (2007). Theorizing Communication: Readings across Traditions. In Sage Publication. Sage Publications.

Rulistyana, E. (2017). Pengetahuan remaja tentang program pendewasaan usia perkawinan (PUP). Jurnal Ners Dan Kebidanan, 4(1), 79-84. https://doi.org/10.26699/jnk.v4i1.ART.p079-84

Sobur, A. (2014). Komunikasi Naratif: Paradigma, Analisis Dan Aplikasi. Remaja Rosdakarya.

Wahyuningrum, D.M., Gani, H.A., Ririanty, M. (2015). Upaya promosi kesehatan pendewasaan usia perkawinan oleh pusat informasi konseling remaja. $E$ Jurnal Pusataka Kesehatan, 3(Kesehatan), 186-192.

West, Richard \& Lynn H, T. (2008). Pengantar Teori Komunikasi Analisis dan Aplikasi (3rd ed.). Salemba Humanika.

West, R., \& Turner, L. H. (2019). Introducing Communication Theory. In Making Sense of Messages. https://doi.org/10.4324/9781351130127-13

Wright-St Clair, V., Reid, D., Shaw, S. and Ramsbotham, J. (2014). Evidence-based Health Practice. Oxford University Press. 